\title{
Grain Yield of Kharif Maize Hybrid (Zea mays L) as Influenced by Doses and Split Application of Nitrogen
}

\author{
Ankita Begam¹, Sujit Adhikary ${ }^{2}$, D.C. Roy ${ }^{3 *}$ and M. Ray ${ }^{1}$ \\ ${ }^{1}$ Department of Agronomy, Bidhan Chandra Krishiviswavidyalaya, \\ Mohanpur-741252, W.B., India \\ ${ }^{2}$ Agricultural and Ecological Research Unit, Indian Statistical Institute, \\ Kolkata 700108, India \\ ${ }^{3}$ Department of LFC, W.B. University of Animal and Fishery Sciences, \\ Mohanpur 741252 W.B, India
}

Corresponding author

\section{A B S T R A C T}

A field experiment was conducted in split plot design with three replication to study the influence of different nitrogen doses and itssplit application on yield of kharif maize(pioneer 3377) in 2017 at B.C.K.V, Gayeshpur farm Nadia, W.B. Four main treatment comprising different nitrogen doses of $\mathrm{M}_{1}-75, \mathrm{M}_{2}-100, \mathrm{M}_{3}-125, \mathrm{M}_{4}-150 \mathrm{~kg} \mathrm{~N} / \mathrm{ha}$ were the in main plots and three type of split application of $N$ i.e $S_{1^{-}} 1 / 2$ as basal $+1 / 2$ at 25

\section{Keywords}

Kharif maizehybrid, Nitrogen, Dose, Split application

Article Info

Accepted:

15 June 2018

Available Online:

10 July 2018

DAS; $S_{2^{-}} 1 / 2$ as basal $+1 / 2$ at 45 DAS; and $S_{3^{-}} 1 / 2$ as basal $+1 / 4$ at 25 DAS $+1 / 4$ at 45 DAS in sub plots respectively.All the yield attributes like cob/plant, cob length, cob diameter, fresh cob weight, grain/cob etc. increased significantly with the increase in $\mathrm{N}$ doses.Higher number of cob per plant (1.24) was recorded with $150 \mathrm{~kg} \mathrm{~N} / \mathrm{ha}\left(\mathrm{M}_{4}\right)$ and lowest in $75 \mathrm{~kg}$ $\mathrm{N} /$ ha. Regarding split applications of nitrogen, treatment $\mathrm{S}_{3}$ i.e $\mathrm{N}$ applied in three split doses at $1 / 2$ as basal $+1 / 4$ at 25DAS + 1/4at 45 DAS; gave the higher cob/plant of 1.31 which was statistically significant over $S_{2}$ and $S_{1}$.Similar trend was also observed in cob length,cob diameter and fresh cob weight.Yield of maize were found significant in both different doses of nitrogen and different split application of nitrogen.Significantly highest grain yield $\left(7.37 \mathrm{t} \mathrm{ha}^{-1}\right)$ was obtained in $150 \mathrm{~kg} \mathrm{~N} / \mathrm{ha}\left(\mathrm{M}_{4}\right)$. Among the different split application pattern of nitrogen, treatment $S_{3}(1 / 2$ as basal $+1 / 4$ at 25 DAS $+1 / 4$ at 45 DAS $)$ recorded the significantly higher yield followed by $S_{1}$ and then $S_{2}$. Interaction effect of different doses andsplit application of nitrogen was found significant in both grain/cob and yield of maize. Among the different treatment combination, $\mathrm{M}_{4} \mathrm{xS}_{3}$ [N @ 150kg/ha with three split application at $1 / 2$ as basal $+1 / 4$ at 25 DAS $+1 / 4$ at 45 DAS] recorded better yield as compare to other treatment combination.

\section{Introduction}

Maize (Zea mays L.) is one of the most important cereal grains grown worldwide in a wider range of environment because of its greater adaptability. It is mainly used as a food source and now has become the most important raw material for animal feed. It is 
one of the most important cereal crops next to Wheat and Rice in the world. In India, about 50 to 55 per cent of the total maize production is consumed as food, 30 to 35 per cent goes for poultry, piggery and fish meal industry and 10 to 12 per cent to wet milling industry. Maize is cultivated in all seasons viz., Kharif, Rabi and Summer.

Maize (Zea mays L.) is a widely grown crop with a high rate of photosynthetic activity because of its $\mathrm{C} 4$ pathway, leading to higher grain yield and biomass potential. In India, maize was grown in area of 8691.2 thousand hectare, with production of $21,806.5$ thousand tones and productivity of $2505.00 \mathrm{~kg}$ $\mathrm{ha}^{-1}$ while in West Bengal the area, production and productivity were 156 thousand hectare, 720 thousand tones and $4615 \mathrm{~kg} \mathrm{ha}^{-1}$ respectively in the year 2015-16 (Anonymous, 2017). Due to immense potential it is called as 'Miracle crop' and also known as a 'Queen of cereals'. Being an exhaustive crop, it has very high nutrient requirement and its productivity depends closely on nutrient requirement and management particularly that of nitrogen, phosphorous and potassium.

Fertilizers play an important role for increasing the maize yield and their contribution is 40-50 \%. Balanced and optimum use of nitrogen, phosphorous and potassium fertilizers play a vital role in increasing the yield of cereal crops. Nitrogen fertilization results in increased grain yield (43-68\%) and biomass (25-42\%) in maize (Ogola et al., 2002). An increase in yield of maize with increasing rate of nitrogen has been reported by many researchers. Nitrogen application in splits proved to be a best practice in sense that it reduced various losses and resulted to higher dry matter accumulation and plant height in maize as compared to sole application as reported by Harikrishna et al., (2005). Though the yield potential of our present varieties is high enough, but it has not been explored fully due to some production constraints. Among the limiting factors; proper level and ratio of nitrogen, phosphorous and potassium are of prime importance. Moreover the nutritional requirements of approved varieties must also be investigated. The development of high yielding hybrids has increased the nutrient requirement of this crop. Hence, there is need to work out a suitable doses of nitrogen fertilizer level and split application of nitrogen on growth and yield of hybrid kharif maize variety.

\section{Materials and Methods}

The present study entitled 'Grain yield of kharif maize hybrid (Zea mays L) as influenced by doses and split application of nitrogen' was conducted at Gayeshpur farm, B.C.K.V., Nadia. Hybrid maize pioneer 3377 variety was sown on $10^{\text {th }}$ June 2017 . Seeds are sown by line sowing. Latitude of the farm was $22^{\circ} 56^{\prime} \mathrm{N}$ having longitude of $88^{\circ} 32^{\prime} \mathrm{E}$ and altitude of $9.75 \mathrm{~m}$ AMSL. The soil type ranges from sandy loam to heavy clay. Soil $\mathrm{pH}$ is about 7-7.4, available $\mathrm{N}$ ranges from 0.227 $0.235 \mathrm{~kg} \mathrm{ha}^{-1}, \mathrm{P}_{2} \mathrm{O}_{5}$ from 23.0 - $25.0 \mathrm{~kg} \mathrm{ha}^{-1}$, $\mathrm{K}_{2} \mathrm{O}: 217.0-226.0 \mathrm{~kg} \mathrm{ha}^{-1}$ and Organic Carbon from $0.470 .54 \%$. Climate in general is of humid sub-tropical type.

The experiment was laid out in a Split Plot Design (SPD) with 3 replications and 12 treatments. Four main treatment comprising different nitrogen doses of $\mathrm{M}_{1}-75, \mathrm{M}_{2}-100, \mathrm{M}_{3}$ $125, \mathrm{M}_{4}-150 \mathrm{~kg} \mathrm{Nha}^{-1}$ were the in main plots and three type of split application of $\mathrm{N}$ basal i.e. $S_{1}-1 / 2$ as basal $+1 / 2$ at 25 DAS; $S_{2^{-}} 1 / 2$ as basal $+1 / 2$ at 45 DAS (Days After Sowing); and $S_{3^{-}}-1 / 2$ as basal $+1 / 4$ at 25 DAS+ $1 / 4$ at 45 DAS in sub plots respectively. The plot size of $4 \mathrm{~m}$ by $3 \mathrm{~m}\left(12 \mathrm{~m}^{2}\right)$ with row to row distance of $60 \mathrm{~cm}$ and plant to plant distance $25 \mathrm{~cm}$ was used. Urea is used as a source of nitrogen. One irrigation was given at 17 DAS. 
Insecticide 'chloropyriphos + cypermethrin' was applied for controlling stem borer. Statistical analysis was done for determining the standard error of mean (S.Em \pm ) and the value of $\mathrm{CD}$ (Critical difference) at 5\% level of significance using methodology as stated in Gomez and Gomez(1984).

\section{Results and Discussion}

\section{Number of Cob per plant}

Data showed that application of different doses of nitrogen levels as well as split application of nitrogen significantly influenced on number of cob/plant. Number of cobs per plant was increased with the increase of nitrogen doses which might be due to better vegetative growth of the plants as reflected by higher plant height, number of leaves per plant, dry matter accumulation. Significantly higher number of cob per plant (1.24) was recorded in $150 \mathrm{~kg} \mathrm{ha}^{-1}\left(\mathrm{M}_{4}\right)$ i.e. $\mathrm{N} @ 150 \mathrm{~kg}$ $\mathrm{ha}^{-1}$ followed by $\mathrm{M}_{3}, \mathrm{M}_{2}$ and the lowest in 75 $\mathrm{kg} \mathrm{ha}^{-1}\left(\mathrm{M}_{1}\right)$. Muniswamy et al., (2007) reported that number of cob per plant was increased with the increase of nitrogen doses and the highest value of 2.12 was obtained with application of $160 \mathrm{~kg}$ of $\mathrm{N} \mathrm{ha}^{-1}$ (Table 1 \& Fig.1).

Regarding split applications, nitrogen applied in three split doses at $1 / 2$ as basal $+1 / 4$ at 25 DAS $+1 / 4$ at 45 DAS resulted maximum cob per plant (1.31) which was statistically significant over $S_{2}$ and $S_{1}$. However the interaction effect of doses and split application of nitrogen on no. of cobs per plant was found statistically non-significant in case of interaction effect(Table $1 \&$ Fig.1).

\section{Cob length}

Cob length up to some extent is related to the number of grains per row and affects the total number of grain per cob and grain yield.
Result presented on table1 shows that nitrogen levels had significant effect on cob length of kharif maize. Cob length per plant differed with different doses of nitrogen application. Higher cob length $(17.89 \mathrm{~cm})$ was recorded from $150 \mathrm{~kg} \mathrm{~N} \mathrm{ha}^{-1}$ which is statistically at par with $125 \mathrm{~kg} \mathrm{~N} \mathrm{ha}^{-1}$ with the cob length of $(17.75 \mathrm{~cm})$ and lowest cob length of $16.32 \mathrm{~cm}$ was found in $75 \mathrm{~kg} \mathrm{~N} \mathrm{ha}^{-1}\left(\mathrm{M}_{1}\right)$ in main plot. Regarding the effect of split application of nitrogen, higher cob length was found in $\mathrm{S}_{3}$ $(18.00 \mathrm{~cm})$ i.e. three split doses at $1 / 2$ as basal + $1 / 4$ at $25 \mathrm{DAS}+1 / 4$ at 45 DAS followed by $\mathrm{S}_{1} \&$ $\mathrm{S}_{2}$ respectively (Table $1 \&$ Fig.2).

However, interaction effect of split application of nitrogen and different nitrogen doses was found not significant in cob length; though the higher cob length of $18.45 \mathrm{~cm}$ was obtained in treatment combination $\mathrm{M}_{4} \mathrm{~S}_{3}$ i.e. $\mathrm{N} @ 150 \mathrm{~kg}$ $\mathrm{ha}^{-1}$ applied in three split doses of $1 / 2$ as basal + $1 / 4$ at 25 DAS $+1 / 4$ at 45 DAS. $M_{4} S_{1}$ treatment was statistically at par with $\mathrm{M}_{4} \mathrm{~S}_{3}$ treatment in cob length among treatment combinations. $\mathrm{M}_{2} \mathrm{~S}_{2}$ treatment combination resulted lowest cob length $(14.40 \mathrm{~cm})$ compare to other treatment (Table $1 \&$ Fig.2).

\section{Cob diameter}

The yield attributes of maize in terms of cob diameter was significantly influenced by nutrient management in main plot and sub plot. From the recorded data it was found that with the increase in nitrogen doses from 75 to $150 \mathrm{~kg} \mathrm{ha}^{-1}$, the cob diameter of maize was increased significantly. Maximum cob diameter $(43.85 \mathrm{~cm})$ was recorded for $150 \mathrm{~kg}$ $\mathrm{N}$ ha ${ }^{-1}\left(\mathrm{M}_{4}\right)$ which was statistically at par with $125 \mathrm{~kg} \mathrm{~N} \mathrm{ha}^{-1}\left(\mathrm{M}_{3}\right)$ and lowest cob diameter of $41.12 \mathrm{~cm}$ was obtained in $75 \mathrm{~kg} \mathrm{~N} \mathrm{ha}^{-1}\left(\mathrm{M}_{1}\right)$. Similarly, Raja (2011) observed that the increase in nitrogen rates application from 0 to $120 \mathrm{~kg} \mathrm{~N} / \mathrm{ha}$ positively improved the cob girth of sweet corn. 
Regarding split applications of nitrogen, treatment $\mathrm{S}_{3}$ i.e. $1 / 2$ as basal $+1 / 4$ at $25 \mathrm{DAS}+1 / 4$ at 45 DAS recorded the highest cob diameter of $43.83 \mathrm{~cm}$ which was statistically at par with $\mathrm{S}_{1}$ but significantly higher over $\mathrm{S}_{2}$. The interaction between different doses of nitrogen doses and split application of nitrogen was not significant with respect to cob diameter.

\section{Fresh cob weight}

The effect of different doses and split application of nitrogen on fresh cob weight of maize was depicted in table 1 and it was found that fresh cob weight was increased with the increase of nitrogen doses from 75 to $150 \mathrm{~kg}$ $\mathrm{ha}^{-1}$. Higher fresh weight of $171.23 \mathrm{~g}$ per cob was obtained from nitrogen dose of $150 \mathrm{~kg} \mathrm{ha}^{-}$ ${ }^{1}\left(\mathrm{M}_{4}\right)$ which was significantly higher over all the other doses of nitrogen in the trial. However lowest fresh weight of cob (106.55 g per cob) was recorded in $75 \mathrm{~kg} \mathrm{~N} \mathrm{ha}^{-1}$.

Effect of split application of nitrogen on fresh cob weight was found statistically significant and the higher fresh weight of cob (153.18 g per cob) was observed in treatment $S_{3}$ i.e. $1 / 2$ as basal $+1 / 4$ at 25 DAS $+1 / 4$ at 45 DAS; which was significantly higher over $S_{2}(1 / 2$ as basal + $1 / 2$ at 45 DAS $)$ and $S_{1}(1 / 2$ as basal $+1 / 2$ at 25 DAS) (Table 1).

Regarding the interaction effect of different doses and split application of nitrogen, it was found that the fresh cob weight of maize was influenced significantly by the said interaction effect and the higher value of $194.58 \mathrm{~g}$ per cob, was obtained in treatment combination $\mathrm{M}_{4} \mathrm{~S}_{3}$ i.e. $\mathrm{N} @ 150 \mathrm{~kg} \mathrm{ha}^{-1}$ applied in three split doses of $1 / 2$ as basal $+1 / 4$ at 25 DAS $+1 / 4$ at 45 DAS (Table 1).

\section{Number of grains per cob}

Number of grains per cobis also vital parameter, which contributes materially towards final yield in maize. The number of grains per cob has a direct influence on the grain yield of maize. Number of grain per cob was found significant in both different doses of nitrogen and different split application of nitrogen. Maximum number of grain per cob (376.59) was recorded by hybrid maize variety pioneer 3377 in $150 \mathrm{~kg} \mathrm{~N}^{-1}\left(\mathrm{M}_{4}\right)$ followed by $125 \mathrm{~kg} \mathrm{~N}^{-1}\left(\mathrm{M}_{3}\right), 100 \mathrm{~kg} \mathrm{~N}^{-1}\left(\mathrm{M}_{2}\right)$ and then $75 \mathrm{~kg} \mathrm{~N} \mathrm{ha}^{-1}\left(\mathrm{M}_{1}\right)$ (Table 1).

Joshi et al., (2014) in M.P reported that maximum number of grains $\operatorname{cob}^{-1}$ (458.76) was obtained with application of $100 \mathrm{~kg}$ of nitrogen than other levels (50 and $75 \mathrm{~kg} \mathrm{ha}^{-1}$ N). however, Tank et al., (2006) observed that maximum number of grains $\mathrm{cob}^{-1}$ (336) was obtained with application of $180 \mathrm{~kg}$ of $\mathrm{N} \mathrm{ha}^{-1}$ than the other levels $\left(0,60\right.$ and $\left.120 \mathrm{~kg} \mathrm{ha}^{-1}\right)$ at Anand, Gujarat.

Regarding the split application of nitrogen, higher no. of grain per cob (355.40) was recorded in treatment $S_{3}$ i.e. $1 / 2$ as basal $+1 / 4$ at 25 DAS $+1 / 4$ at 45 DAS which was significantly higher over $S_{2}(1 / 2$ as basal $+1 / 2$ at 45 DAS $)$ and at par with $S_{1}(1 / 2$ as basal $+1 / 2$ at 25 DAS)(Table 1).

Interaction effect of different nitrogen doses and split application of nitrogen was also found significant in no. of grains per cob and the significantly higher value of 394.57 was obtained in treatment combination $\mathrm{M}_{4} \mathrm{~S}_{3}$ i.e. $\mathrm{N}$ @ $150 \mathrm{~kg} \mathrm{ha}^{-1}$ applied in three split doses of $1 / 2$ as basal $+1 / 4$ at $25 \mathrm{DAS}+1 / 4$ at $45 \mathrm{DAS}$. $\mathrm{M}_{2} \mathrm{~S}_{2}$ treatment combination resulted the significantly lowest grain per cob (291.40) compare to other treatment (Table 1).

\section{Seed Index (100 grains weight)}

Seed index of maize grain (100 seed wt.) was found statistically not significant in different doses of nitrogen, different split applications of nitrogen as well as their interaction effect. 
Table.1 Effect on yield parameters and yield of kharif maize hybrid variety

\begin{tabular}{|c|c|c|c|c|c|c|c|}
\hline Treatments & $\begin{array}{c}\text { Cob } \\
\text { plant }^{-1}\end{array}$ & $\begin{array}{c}\text { Cob } \\
\text { length } \\
(\mathrm{cm})\end{array}$ & $\begin{array}{c}\text { Cob } \\
\text { Diameter } \\
(\mathbf{c m})\end{array}$ & $\begin{array}{c}\text { Fresh cob } \\
\text { weight } \\
\text { (g cob-1) }\end{array}$ & $\begin{array}{c}\text { Grain } \\
\text { cob }^{-1}\end{array}$ & $\begin{array}{c}\text { Seed } \\
\text { Index(g) }\end{array}$ & $\begin{array}{c}\text { Grain } \\
\text { yield } \\
\left(\mathrm{t} \mathrm{ha}^{-1}\right)\end{array}$ \\
\hline \multicolumn{8}{|c|}{ Main plots (Fertilizer dose) } \\
\hline $\mathbf{M}_{1}$ & 1.10 & 16.32 & 41.12 & 106.55 & 303.24 & 25.28 & 6.19 \\
\hline $\mathbf{M}_{2}$ & 1.15 & 16.72 & 42.09 & 128.36 & 331.95 & 25.37 & 6.38 \\
\hline $\mathbf{M}_{3}$ & 1.20 & 17.75 & 43.28 & 147.56 & 349.87 & 25.45 & 7.14 \\
\hline $\mathbf{M}_{4}$ & 1.24 & 17.89 & 43.85 & 171.23 & 376.59 & 25.48 & 7.37 \\
\hline S.Em $( \pm)$ & 0.03 & 0.29 & 0.34 & 2.85 & 8.05 & 0.767 & 0.26 \\
\hline C.D. $(0.05)$ & 0.08 & 1.02 & 1.16 & 9.87 & 27.85 & NS & 0.89 \\
\hline \multicolumn{8}{|c|}{ Sub plots (Split application) } \\
\hline $\mathbf{S}_{1}$ & 1.17 & 17.71 & 42.77 & 140.00 & 342.05 & 25.40 & 6.80 \\
\hline $\mathbf{S}_{2}$ & 1.05 & 15.80 & 41.16 & 122.10 & 323.80 & 25.37 & 6.46 \\
\hline $\mathbf{S}_{3}$ & 1.31 & 18.00 & 43.83 & 153.18 & 355.40 & 25.42 & 7.05 \\
\hline S.Em ( $( \pm)$ & 0.03 & 0.41 & 0.45 & 3.41 & 9.45 & 0.93 & 0.29 \\
\hline C.D. $(0.05)$ & 0.10 & 1.23 & 1.35 & 10.23 & 28.33 & NS & 0.89 \\
\hline \multicolumn{8}{|c|}{ Interaction $(\mathbf{M} \times \mathbf{S})$} \\
\hline $\mathbf{M}_{1} \mathbf{S}_{1}$ & 1.12 & 17.01 & 41.08 & 108.46 & 300.88 & 25.28 & 6.18 \\
\hline $\mathbf{M}_{1} \mathbf{S}_{2}$ & 1.01 & 14.41 & 40.14 & 102.22 & 291.40 & 25.27 & 6.11 \\
\hline $\mathbf{M}_{1} \mathbf{S}_{3}$ & 1.18 & 17.54 & 42.14 & 108.97 & 317.44 & 25.29 & 6.28 \\
\hline $\mathbf{M}_{2} \mathbf{S}_{1}$ & 1.13 & 17.78 & 42.49 & 130.24 & 335.64 & 25.34 & 5.68 \\
\hline $\mathbf{M}_{2} \mathbf{S}_{2}$ & 1.05 & 14.40 & 40.53 & 114.56 & 316.50 & 25.39 & 6.58 \\
\hline $\mathbf{M}_{2} \mathbf{S}_{3}$ & 1.27 & 17.98 & 43.25 & 140.28 & 343.71 & 25.38 & 6.88 \\
\hline $\mathbf{M}_{3} \mathbf{S}_{1}$ & 1.20 & 17.84 & 43.54 & 142.75 & 354.77 & 25.47 & 6.94 \\
\hline $\mathbf{M}_{3} \mathbf{S}_{2}$ & 1.06 & 17.37 & 41.63 & 131.04 & 328.97 & 25.40 & 7.07 \\
\hline $\mathbf{M}_{3} \mathbf{S}_{3}$ & 1.35 & 18.04 & 44.67 & 168.89 & 365.87 & 25.48 & 7.41 \\
\hline $\mathbf{M}_{4} \mathbf{S}_{1}$ & 1.22 & 18.21 & 43.97 & 178.54 & 376.89 & 25.50 & 7.05 \\
\hline $\mathbf{M}_{4} \mathbf{S}_{2}$ & 1.07 & 17.01 & 42.34 & 140.57 & 358.31 & 25.40 & 7.42 \\
\hline $\mathbf{M}_{4} \mathbf{S}_{3}$ & 1.44 & 18.45 & 45.24 & 194.58 & 394.57 & 25.54 & 7.64 \\
\hline \multicolumn{8}{|l|}{$[\mathbf{M} \times \mathbf{S}]$} \\
\hline S.Em $( \pm)$ & 0.13 & 1.36 & 0.82 & 5.08 & 10.08 & 1.04 & 0.34 \\
\hline C.D. $(0.05)$ & NS & NS & 2.45 & 15.26 & 30.25 & NS & 1.01 \\
\hline \multicolumn{8}{|l|}{$[\mathbf{S} \times \mathbf{M}]$} \\
\hline S.Em ( $( \pm)$ & 0.15 & 0.42 & 0.82 & 5.68 & 10.59 & 1.18 & 0.35 \\
\hline C.D. $(0.05)$ & NS & NS & 2.65 & 18.35 & 34.21 & NS & 1.10 \\
\hline
\end{tabular}


Fig.1 Effect of different doses and split application of nitrogen on no. of cob/plant in main plot and sub-plot

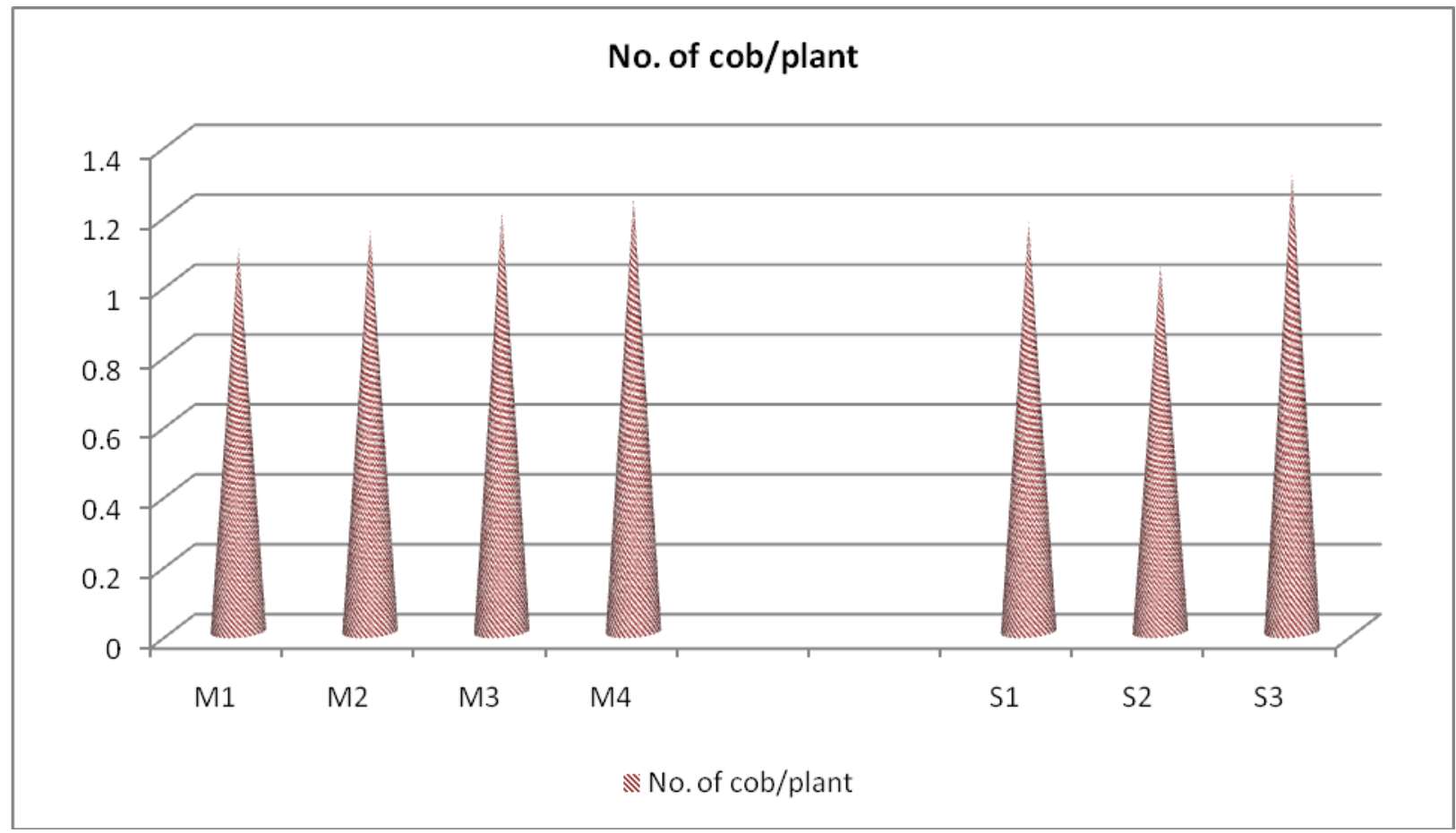

Fig.2 Effect of different doses and split application of nitrogen on cob length in main plot and sub-plot

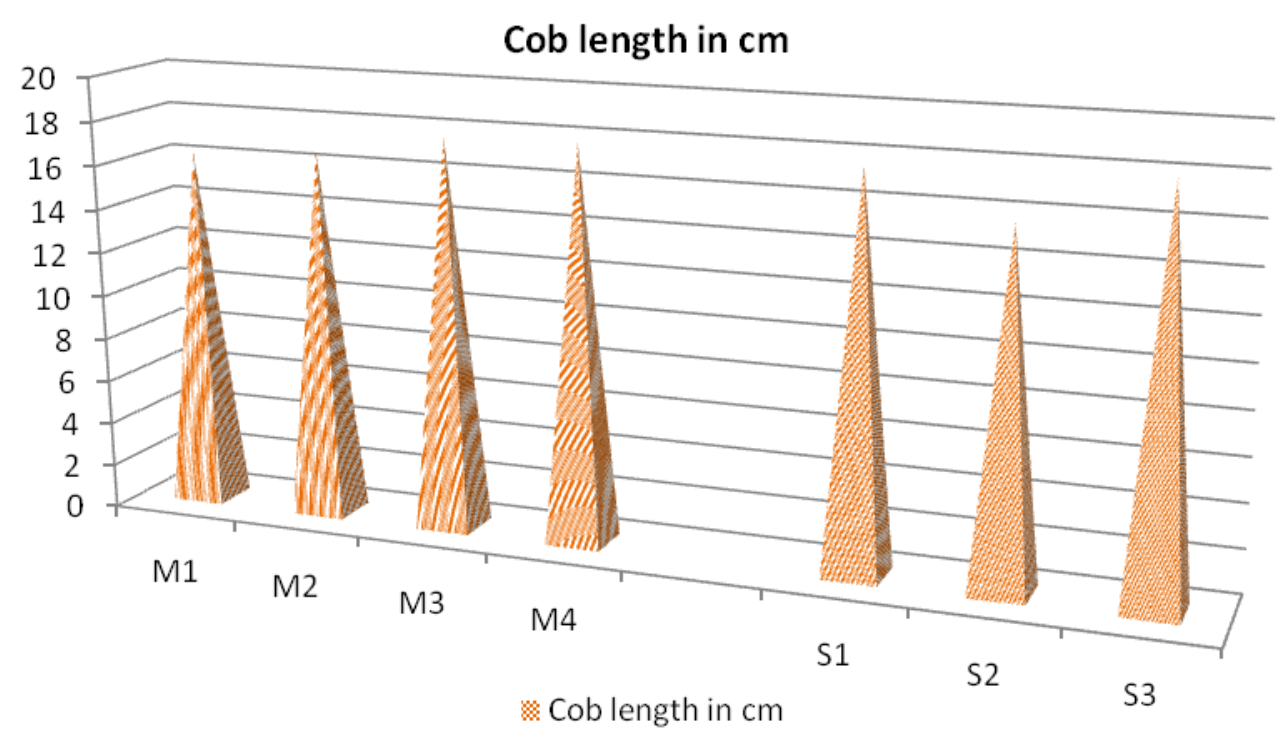


Fig.3 Effect of different doses and split application of nitrogen on grain yield in main plot and sub-plot

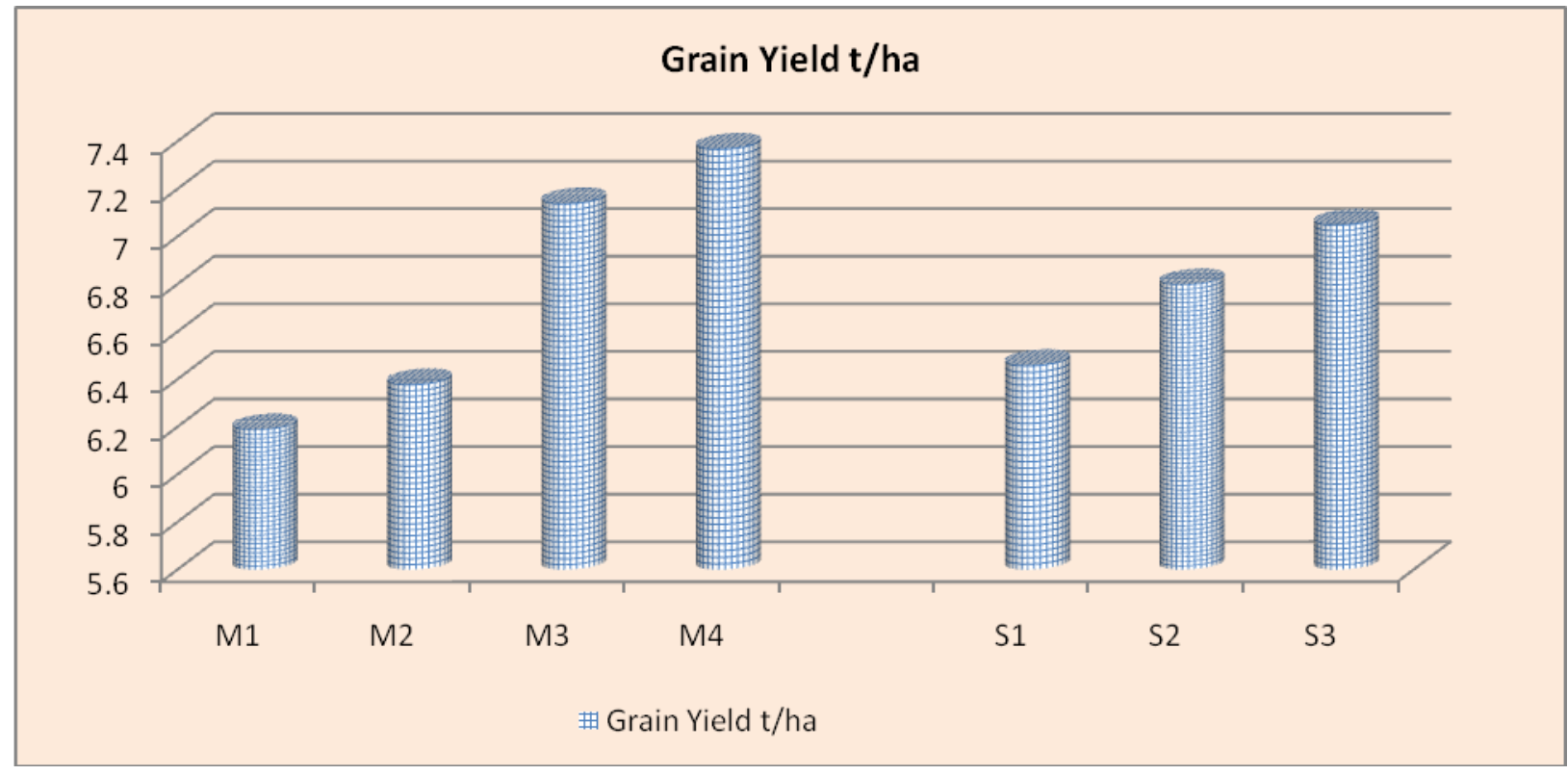

Fig.4 Interaction effect of different doses and split application of $\mathrm{N}$ on grain yield

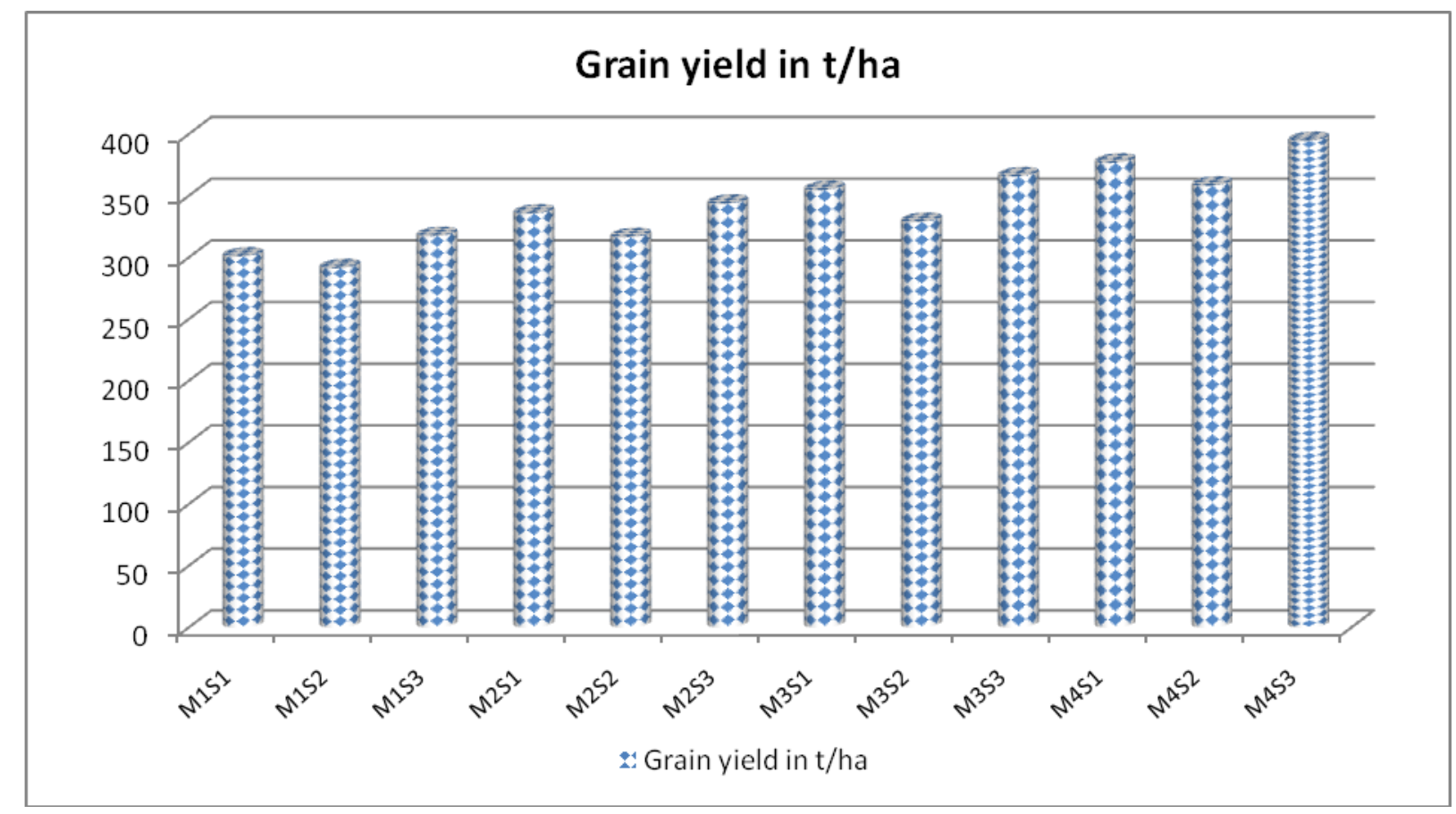




\section{Grain yield}

Grain yield of a crop is an important tool to assess the effect of technologies or factors on it and for making profitable return to the farmers. The dry matter produced during the vegetative growth phase of the plant is ultimately regulating the amount of economic yield of the crop.

The grain yield of hybrid maize (P3377) was significantly influenced by both different doses of nitrogen doses and split application of nitrogen in new alluvial soils of West Bengal during kharif season of 2017. The highest grain yield of $7.37 \mathrm{t} \mathrm{ha}^{-1}$ was recorded with $150 \mathrm{~kg} \mathrm{~N}^{-1}$ which was statistically at par with that of $125 \mathrm{~kg} \mathrm{~N} \mathrm{ha}^{-1}$ with a yield of $7.14 \mathrm{tha}^{-1}$ and significantly lowest yield was obtained from $75 \mathrm{~kg} \mathrm{~N}^{-1}{ }^{-1}$ in main plot. The results might be attributed to higher number of cob per plant, grain per cob and seed index (Table 1 \& Fig.3). Similar trend was also observed by Verma et al., (2012) who reported that application of $\mathrm{N} @ 150 \mathrm{~kg}$ $\mathrm{ha}^{-1}$ significantly increased the yield and yield parameter of hybrid maize over 100 and $50 \mathrm{~kg}$ $\mathrm{Nha}^{-1}$.

Among the different split application pattern of nitrogen, treatment $S_{3}$ i.e. $1 / 2$ as basal $+1 / 4$ at $25 \mathrm{DAS}+1 / 4$ at 45 DAS gave the highest yield $\left(7.05 \mathrm{t} \mathrm{ha}^{-1}\right)$ followed by $\mathrm{S}_{1}$ and then $\mathrm{S}_{2}$ (Table $1 \&$ Fig.3). The interaction effect of hybrid kharif maize variety under different doses of nitrogen doses and split application of nitrogen was found non-significant on grain yield of hybrid kharif maize. Interaction effect of treatment combination $\mathrm{M}_{4} \mathrm{~S}_{3}$ i.e. $\mathrm{N} @$ $150 \mathrm{~kg} \mathrm{ha}^{-1}$ applied in three split doses of $1 / 2$ as basal $+1 / 4$ at 25 DAS $+1 / 4$ at 45 DAS gave the better performance among all the treatment combinations(Table $1 \&$ Fig.4).

In conclusion, however, from this one year experiment it can be concluded that the yield components were significantly influenced by the different dose of nitrogen doses and split application of nitrogen. Nitrogen doses had pronounced effect on yield attributes and grain yield of hybrid maize. Yield and yield traits gradually increased with increasing nitrogen doses from 75 to $150 \mathrm{~kg} \mathrm{ha}^{-1}$. Number of cobs per plant and cob length varied with different doses of nitrogen fertilizer. Among the different doses of nitrogen treatment $\mathrm{M}_{4}$ i.e. $\mathrm{N} @ 150 \mathrm{~kg} \mathrm{ha}^{-1}$ gave the better result. The response to nitrogen increases as level of nitrogen applied increased. Regarding the different split application pattern of nitrogen, treatment $\mathrm{S}_{3}$ i.e. $1 / 2$ as basal $+1 / 4$ at 25 DAS $+1 / 4$ at 45 DAS showed better performance followed by $S_{1}$ and then $S_{2}$. Interaction effect of treatment combination $\mathrm{M}_{4} \mathrm{~S}_{3}$ i.e. $\mathrm{N} @ 150 \mathrm{~kg} \mathrm{ha}^{-1}$ applied in three split doses of $1 / 2$ as basal $+1 / 4$ at 25 DAS $+1 / 4$ at 45DAS gave the better performance among all the treatment combinations.

\section{References}

Anonymous, 2017.Director's Review (201617). ICAR-Indian Institute of Maize Research, Ludhiana.8-12.

Gomez K.A. and Gomez A.A. 1984. Statistical Procedure of Agricultural Research. John Wiley and Sons, New York, USA.200-15.

Harikrishna B. L., Das G. S. and Patil P. L. 2005. Effect of soil depths, N-doses and its split application on maize plant height, LAI and dry matter yield at different growth stages, Karnataka $J$ AgricSci 18: 364-69.

Joshi A, Gupta J K, Choudhary S K, Mujalde S and Garg M 2014. Effect of nitrogen sources, doses and split applications on yield and economics of maize (Zea mays L.) in the Malwa region of Madhya Pradesh (India).J. Agri. Vet. Sci.7: 24-28.

Muniswamy S., Rami Gowda and Rajendra 
Prasad S. 2007.Effect of spacing and fertilizer levels on seed yield and quality of maize single cross hybrid PEMH-2.Mysore Journal Agric.Sci.. 41(2):186-90.

Ogola J.B.O., Wheeler T.R., Harris P.M. 2002. Effects of nitrogen and irrigation on water use of maize crops. Field crop Res. 78: 105-117.

Raja V. 2011.Effect of nitrogen and plant population on yield and quality of super sweet corn (Zea mays) Indian J.Agron. 46(2):246-49.

Tank D.A, Patel, S.K and Usadadia, V.P
2006. Nitrogen management inrabi maize (zea mays L.). Crop Research. 31(2): 323-24.

Verma G, Sharma R.P, Sharma S.P, Subehia S.K, Sambhavi S. 2012.Changes in soil fertility status of maize-wheat system due to long-term use of chemical fertilizers and amendments in an alfisol. Plant Soil Enviroment. 58 (12): 529-33.

Wadsworth, G., 2002, In. Forage Maize Fertilizer Requirement, Potash Development Association, Brixtarw, pp. 25-29.

\section{How to cite this article:}

Ankita Begam, Sujit Adhikary, D.C. Roy and Ray, M. 2018. Grain Yield of kharif Maize Hybrid (Zea mays L) as Influenced by Doses and Split Application of Nitrogen. Int.J.Curr.Microbiol.App.Sci. 7(07): 2121-2129. doi: https://doi.org/10.20546/ijcmas.2018.707.249 